\title{
Bortezomib-resistance is associated with increased levels of proteasome subunits and apoptosis-avoidance
}

\author{
Yi-Xin Wu ${ }^{1}$, Jia-Hua Yang ${ }^{2}$, Hirotomo Saitsu ${ }^{1}$ \\ ${ }^{1}$ Department of Biochemistry, Hamamatsu University School of Medicine, Hamamatsu, Japan \\ ${ }^{2}$ Department of General Surgery, Putuo Hospital, Shanghai University of Traditional Chinese Medicine, Shanghai, China \\ Correspondence to: Yi-Xin Wu, email: yixinwu@hama-med.ac.jp \\ Keywords: bortezomib resistant, proteasome inhibitor, hepatocellular carcinoma cell, BCL2, apoptosis \\ Received: August 02, 2016 \\ Accepted: October 04, 2016 \\ Published: October 18, 2016
}

\section{ABSTRACT}

Bortezomib (BTZ), a proteasome inhibitor, is the first proteasome inhibitor to be used in clinical practice. Here we investigated the mechanisms underlying acquired bortezomib resistance in hepatocellular carcinoma (HCC) cells. Using stepwise selection, we established two acquired bortezomib-resistant HCC cell lines, a bortezomib-resistant HepG2 cell line (HepG2/BTZ) and bortezomib-resistant HuH7 cell line (HuH7/BTZ). The $50 \%$ inhibitory concentration values of HepG2/BTZ and HuH7/BTZ were respectively 15- and 39-fold higher than those of parental cell lines. Sequence analysis of the bortezomib-binding pocket in the $\beta 5$-subunit showed no mutation. However, bortezomib-resistant HCC cells had increased expression of $\beta 1$ and $\beta 5$ proteasome subunits. These alterations of proteasome expression were accompanied by a weak degree of proteasome inhibition in bortezomibresistant cells than that in wild-type cells after bortezomib exposure. Furthermore, bortezomib-resistant HCC cells acquired resistance to apoptosis. Bortezomib upregulated pro-apoptotic proteins of the Bcl-2 protein family, Bax and Noxa in wildtype HCC cells. However, in bortezomib-resistant HCC cells, resistance to apoptosis was accompanied by loss of the ability to stabilize and accumulate these proteins. Thus, increased expression and increased activity of proteasomes constitute an adaptive and auto regulatory feedback mechanism to allow cells to survive exposure bortezomib.

\section{INTRODUCTION}

Hepatocellular carcinoma (HCC) is the most common primary liver cancer. The annual number of new $\mathrm{HCC}$ cases is more than one million, making it the fifth most common cancer worldwide and the third leading cause of cancer-related death [1,2]. Surgery is currently the most effective treatment. However, it is only possible in a few patients (around 40\%) [3]. Thus pharmacotherapy is considered to be the final and main treatment option for patients with advanced HCC. Regrettably, existing traditional chemotherapeutics have significant side effects. Moreover, the most patients with HCC have impaired liver function; aggressive medical therapy cannot be applied. Therefore, no effective treatment can be provided to these patients. Accordingly, there is need to develop novel therapies for HCC. In order to overcome these unsatisfactory aspects, several studies have been performed to elucidate the molecular mechanisms underlying HCC development and progression to identify targets for HCC treatment [4].

Recent studies have been shown that the activities of proteasome in tumor cells are higher than in normal cells. Furthermore, a number of proteasome substrates which are involved in cell cycle or apoptosis have been identified [5]. In many types of tumor cells, inhibition of proteasome activity leads to the accumulation several target proteins, such as IkB- $\alpha$, Bax and p27, and subsequent induction cell cycle arrest or of apoptosis [6]. Therefore, proteasome inhibitors have been focused as a potential anticancer drug. Bortezomib, a proteasome inhibitor, is the first as an anti-cancer drug 
to clinical application, has been used in treatment of non-Hodgkin's lymphoma and multiple myeloma [7, 8]. Preclinical and clinical trials in both hematological malignancies and solid tumors have demonstrated that bortezomib is a relatively well-tolerated and active agent either as a single agent or in combination with traditional chemotherapeutic drugs [9-12]. The results of clinical trials of bortezomib in solid tumors suggest that the molecular targets of bortezomib in solid tumors are different from those reported in hematological malignancies. A phase I/II trial of bortezomib in patients with unresectable HCC has shown that bortezomib appears to be well tolerated in HCC patients $[13,14]$.

In many cases, bortezomib treatment develops rapidly in drug resistance. It is unfortunate that the mechanisms of resistance to bortezomib are poorly understood. Therefore, to develop the novel approaches to overcome bortezomib resistance, there is necessary to understand the mechanisms underlying this resistance. Recently, some mechanisms of proteasome resistance have been determined. Studies have showed that the bortezomib resistance in lymphoma and leukemia cell lines is due to mutations in the $\beta 5$-subunit and $\beta 5$ proteasome subunit overexpression [15-17]. One possibility is upregulation of the pathways that suppress apoptosis [18-24]. An association has been reported between overexpression of heat shock protein (HSP) 27 and bortezomib resistance in lymphoma cells $[25,26]$. However, the mechanisms of bortezomib resistance in liver cancer are not yet clear.

To investigate the possible mechanisms of resistance to bortezomib in liver cancer, we established acquired bortezomib-resistant HCC cell lines, HepG2/BTZ and HuH7/BTZ. We examined the differential effects of bortezomib in wild-type and bortezomib-resistant HCC cell lines and found acquired resistance to apoptosis in these resistant cells. The cause of the resistance was due to loss of the ability to stabilize and accumulate proapoptotic proteins.

\section{RESULTS}

\section{Acquired resistance to bortezomib in HepG2/ BTZ and HuH7/BTZ cells}

Two bortezomib-resistant HCC cell lines, HepG2/ BTZ and HuH7/BTZ, and their wild-type cells were examined for growth inhibition by bortezomib. Growth inhibition dose-response curves of bortezomib-induced cell showed 15-fold $\left(\mathrm{IC}_{50}: 235 \mathrm{nM}\right)$ and 39 -fold $\left(\mathrm{IC}_{50}\right.$ : $1178 \mathrm{nM}$ ) levels of resistance in HepG2/BTZ and HuH7/BTZ cells, respectively, compared with those in their wild-type cells, wild-type HepG2 ( $\left.\mathrm{IC}_{50} 15.6 \mathrm{nM}\right)$ and wild-type $\mathrm{HuH} 7\left(\mathrm{IC}_{50} 30.3 \mathrm{nM}\right)$ cells after 72-h of treatment (Figure 1A and Table 1). In addition, HepG2/ BTZ and HuH7/BTZ cells revealed cross-resistance to another proteasome inhibitor, MG132, but not to doxorubicin (Table 1).

\section{Bortezomib-resistant $\mathrm{HCC}$ cells are lost the ability to accumulate polyubiquitinated proteins in response to bortezomib}

Bortezomib induced inhibition of protein degradation has accompanied accumulation of polyubiquitinated proteins. To investigate alteration of the protein degradation response to bortezomib in resistant $\mathrm{HCC}$ cells, polyubiquitinated proteins in bortezomib-resistant and wild-type HCC cells treatment with bortezomib for $72 \mathrm{~h}$ were checked using western blot analysis. Consistently, increases of polyubiquitinated proteins were observed in wildtype HCC cells but not in bortezomib-resistant cells at their selective concentration of 10-50 nM bortezomib (Figure 1B). However, the bortezomib-resistant cells showed accumulation of polyubiquitinated proteins upon exposure to bortezomib concentrations above the selective concentrations, $>250 \mathrm{nM}$ in HepG2/BTZ and $>1000 \mathrm{nM}$ in HuH7/RTZ (Figure 1B). Thus, bortezomibresistant cells maintained their ability to accumulate ubiquitinated proteins, although this process occurred at higher bortezomib concentrations consistent with the resistance factor of bortezomib.

\section{Chymotrypsin-like and peptidylglutamyl-peptide hydrolyzing (PGPH) activities in bortezomib- resistant HCC cells are inhibited by much higher concentrations of bortezomib than in wild-type cells}

To characterize the activity of the ubiquitinproteasome system in bortezomib-resistant HCC cell lines, we examined the inhibition of proteasome subunits activities in HepG2/BTZ, HuH7/BTZ cells and wildtype cells. In wild-type cells, after $24 \mathrm{~h}$ of treatment to bortezomib, levels of inhibition of chymotrypsin-like and PGPH activities were similar (Figure 2, left panel). For an $80 \%$ reduction in chymotrypsin-like and $\mathrm{PGPH}$ activities, concentrations ranging of bortezomib from 30 to $60 \mathrm{nM}$ in wild-type HepG2 cells and 45 to $75 \mathrm{nM}$ in wild-type $\mathrm{HuH7}$ cells, respectively, were required. On the other hand, the trypsin-like activity was only slightly suppressed by a high bortezomib concentration of $200 \mathrm{nM}$. Compared to wild-type HCC cells, the bortezomib-resistant HCC cells required 3-4-fold higher bortezomib concentration to obtain similar inhibition of chymotrypsin-like and PGPH activities (Figure 2, right panel). Bortezomib did not inhibit the trypsin-like activity in HepG2/BTZ and HuH7/RTZ cells. These results demonstrated that after bortezomib exposure, the degree of proteasome inhibition is weaker in bortezomib-resistant HCC cells than in wildtype cells. 


\section{Bortezomib-resistant $\mathrm{HCC}$ cells show changes in proteasome subunits activities due to increased expression of proteasome subunits}

We next determined basal proteasome activities of bortezomib-resistant HCC cell lines in comparison with their parental cells. The basal activities of chymotrypsinlike and PGPH activities were 2.8- and 6-fold higher (P $<0.01$ ) in HepG2/BTZ cells, and PGPH activity was 1.9-fold higher $(\mathrm{P}<0.01)$ in HuH7/RTZ cells (Figure 3A). Statistical analysis showed a correlation between high basal chymotrypsin-like and PGPH activities and inherent bortezomib resistance $(\mathrm{P}<0.01)$. Notable, no differences were detected in trypsin-like activity, means that the $\beta 2$-subunit is not targeted by bortezomib. To investigate whether the increased proteasome subunit activities in bortezomib-resistant HCC cells might due to altered proteasome subunit expression, we determined the expression of proteasome subunit in $\mathrm{HepG} 2 / \mathrm{BTZ}$ and HuH7/BTZ cells and their wild-type cells by western blot analyses (Figure 3B). Overall, higher expression of proteasome was seen in bortezomib-resistance cells compared to wild-type cells. The levels of $\beta 1$ and $\beta 5$ subunit expression were higher $(\mathrm{P}<0.01)$ in $\mathrm{HepG} / \mathrm{BTZ}$ cells, and $\beta 2$ subunit expression was higher $(\mathrm{P}<0.01)$ in HuH7/RTZ cells (Figure 3B). These results demonstrate that the increased proteasome proteolytic activities in bortezomib-resistant HCC cells were caused by increased expression of proteasome subunits.

\section{Bortezomib-resistant HCC cells exhibit acquired resistance to apoptosis}

It has been reported that bortezomib induce apoptosis in HCC cells. To confirm whether the resistance to bortezomib in HCC cells was correlated by apoptotic signaling, we examined the characteristics of resistant HCC cells, particularly apoptosis-regulating signals. As shown in Figure 4, resistant HCC cells exhibited resistance to apoptosis. Resistant HCC cells and their parental cells were treated with bortezomib for $48 \mathrm{~h}$, and then cell viability and caspase- 3 activity were measured.

A
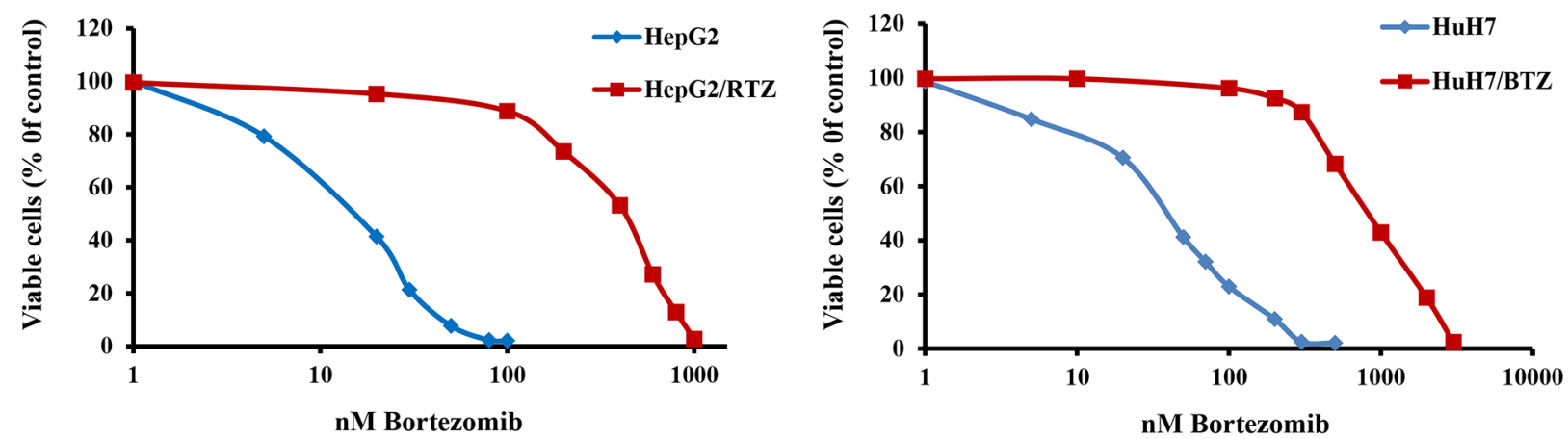

B
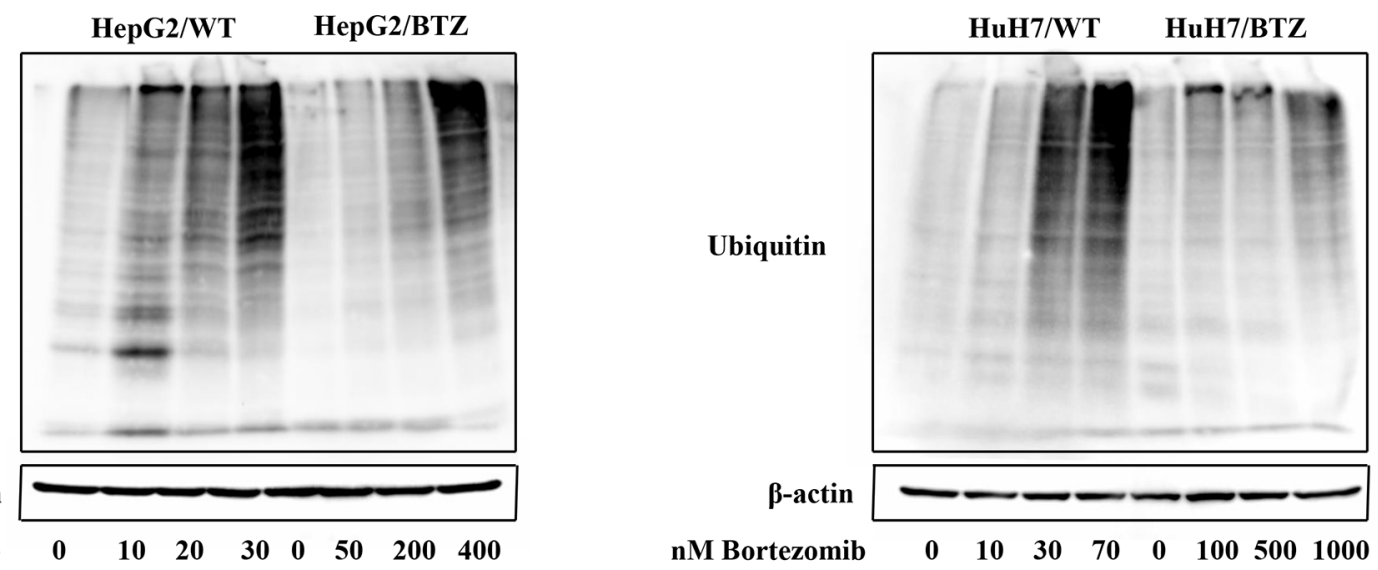

Figure 1: Resistance to the proteasome inhibitor bortezomib in bortezomib-resistant HCC cell lines HepG2/RTZ and HuH7/RTZ. A. Dose-response curve of bortezomib-induced growth inhibition of wild-type HepG2 cells and bortezomib-resistant HepG2/RTZ cells. After treatment with various concentrations of bortezomib for $72 \mathrm{~h}$, cell viability was measured using MTT assays. B. Bortezomib-resistant HCC cells demonstrate diminished accumulation of ubiquitinated proteins. Bortezomib-resistant HCC cells and their parental cells were treated with various concentrations of bortezomib for $72 \mathrm{~h}$. Western blot analysis was performed using a monoclonal antibody against polyubiquitinated proteins. 
Table 1: The $\mathrm{IC}_{50}$ values for each drug in HepG2 /BTZ, HuH7 /BTZ and their parental cell lines. The ratio of IC value of resistant to parental cell line is shown on the right.

\begin{tabular}{lcccccc}
\hline \multirow{2}{*}{ Drug } & \multicolumn{2}{c}{$\mathbf{I C}_{\mathbf{5 0}}(\mathbf{n M})$} & $\mathbf{I C}_{\mathbf{5 0}}$ ratio & \multicolumn{2}{c}{$\mathbf{I C}_{\mathbf{5 0}}(\mathbf{n M})$} & IC $_{\mathbf{5 0}}$ ratio \\
\cline { 2 - 7 } & HepG2 & HepG2/RTZ & & HuH7 & HuH7/RTZ & \\
\hline Bortezomib & 14.7 & 221 & 15.03 & 30.03 & 1178 & 38.9 \\
MG132 & 370 & 2700 & 7.3 & 350 & 3100 & 8.9 \\
Doxorubicin & 205 & 307 & 1.48 & 1112 & 1902 & 1.71 \\
\hline
\end{tabular}

Chymotrypsin-like activity

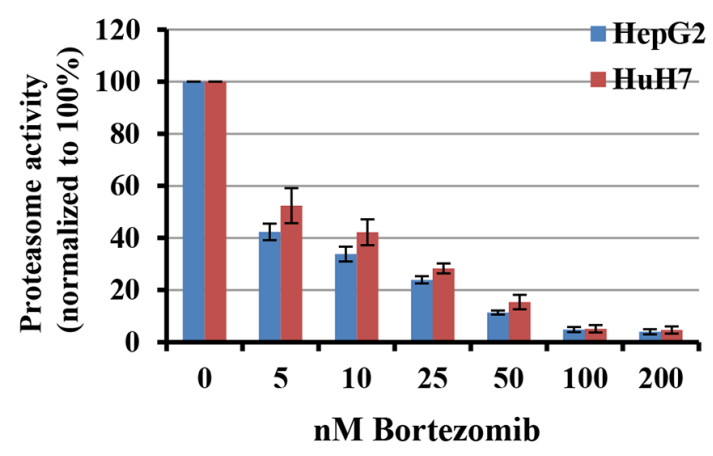

PGPH activity

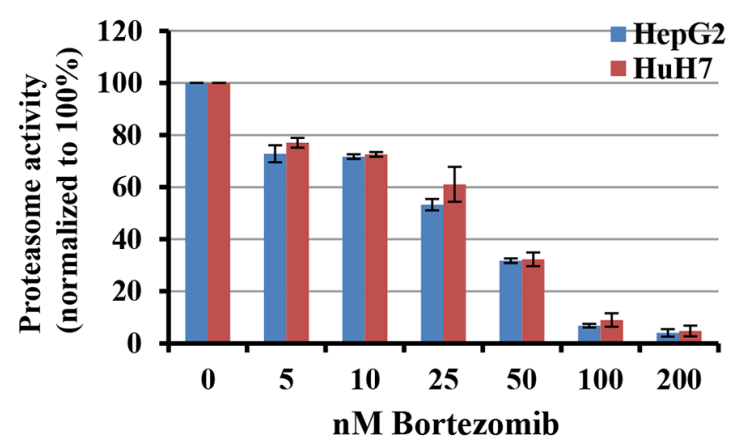

Trypsin-like activity

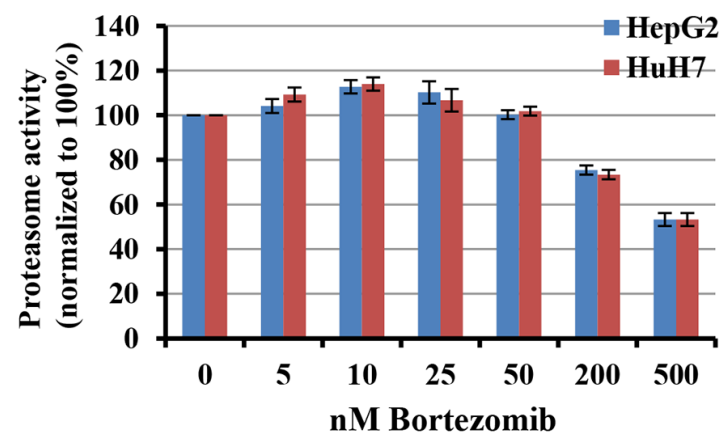

Chymotrypsin-like activity

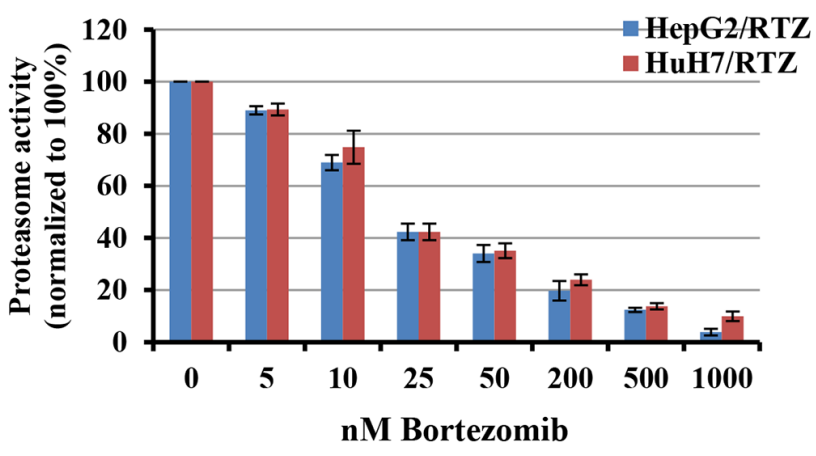

PGPH activity

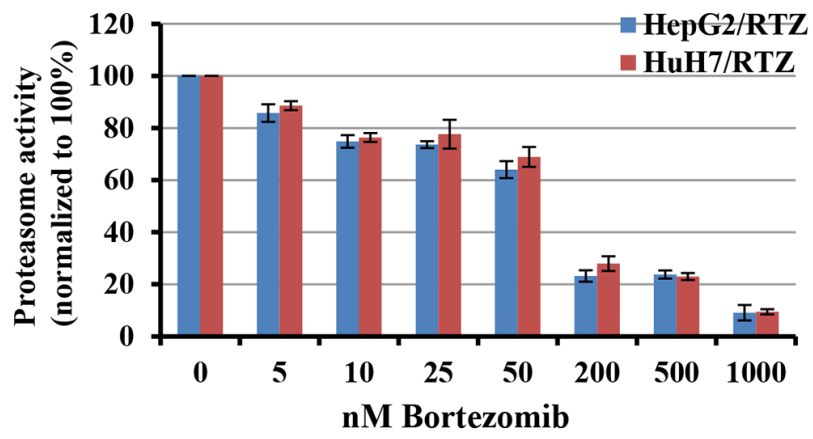

Trypsin-like activity

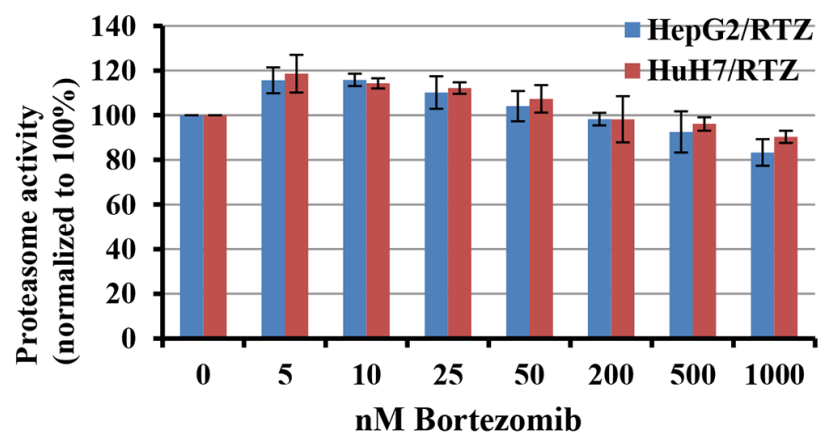

Figure 2: Bortezomib-induced inhibition of proteasome activities in parental and bortezomib-resistant HCC cells. Chymotrypsin-, caspase- and trypsin-like activities were determined using intact cells after treatment with a concentration range of bortezomib for $24 \mathrm{~h}$. Proteasome activities were normalized to untreated cells, which were set at $100 \%$. Bortezomib-resistant cells (right panel) required higher bortezomib concentrations for proteasome inhibition comparable with the parental cells. All results represent the mean \pm SEM of at least three experiments. 
Caspase-3 activity was increased in all bortezomib treated wild-type cells in a dose-dependent manner. Compared with wild-type cells, bortezomib-induced caspase- 3 activity and the percentage of cell death appeared to be lower in bortezomib-resistant HCC cells (Figure 4A). The expression of apoptosis-associated proteins was investigated in HepG2/BTZ, HuH7/BTZ cells and their wild-type cells. Activation of caspases-3 and cleavage of poly (ADP)-ribose polymerase (PARP) were investigated by western blotting after $48 \mathrm{~h}$ of exposure. As shown in Figure 4B, slightly increase in the activation of caspase-3 and subsequent cleavage of PARP after treatment with bortezomib in all wild-type HCC cells but not in bortezomib-resistant HCC cells. Additionally, we performed a time-dependent analysis of capase-3 activity, cell viability, and the expression of apoptosisassociated proteins in bortezomib-resistant HCC cells and wild-type cells. As shown in Figure 5, caspase-3 activity, the percentage of cell death, and the expression of apoptosis-associated proteins were increased in all bortezomib treated wild-type cells in a time-dependent manner. However, compared with wild-type cells, bortezomib-induced caspase-3 activity, the percentage of cell death, and the expression of apoptosis-associated proteins appeared to be failed to increase in response to in bortezomib-resistant HCC cells. These results demonstrated that the resistance to bortezomib in HCC cells was correlated by apoptotic signaling.

\section{Bortezomib-resistant HCC cells loss the ability to stabilize and accumulate pro-apoptotic proteins}

Bax, Noxa and other Bcl-2 proteins are involved in regulation of apoptosis signal induced by bortezomib. Therefore we detected any differences in the expression
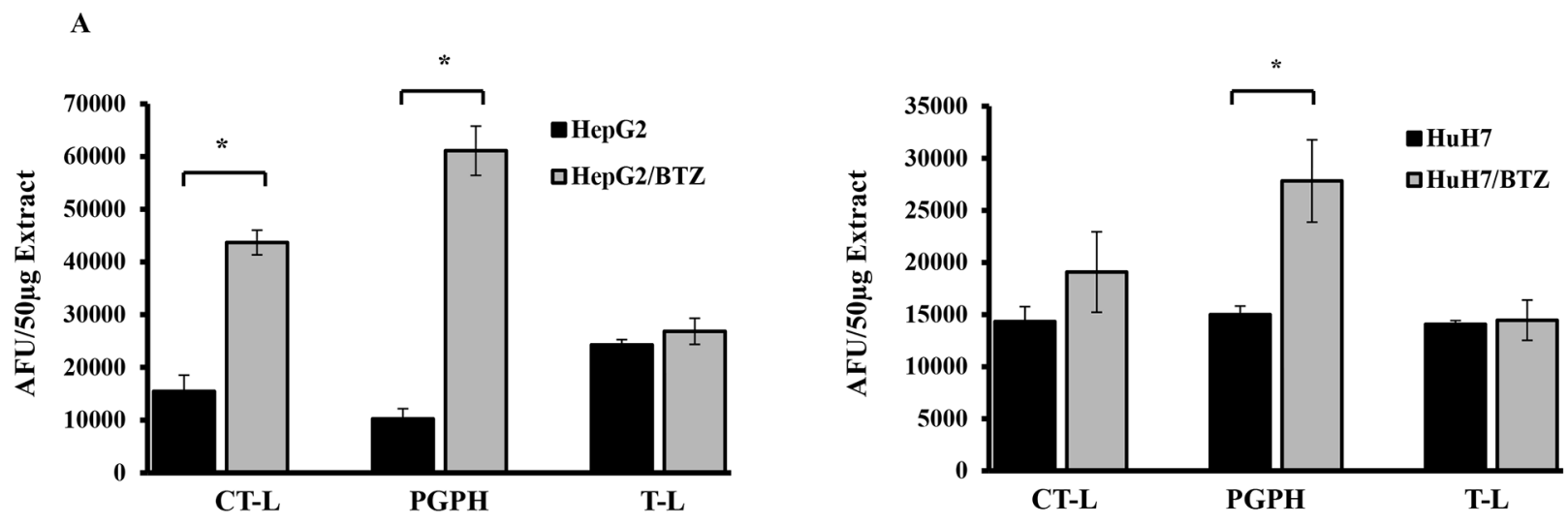

B
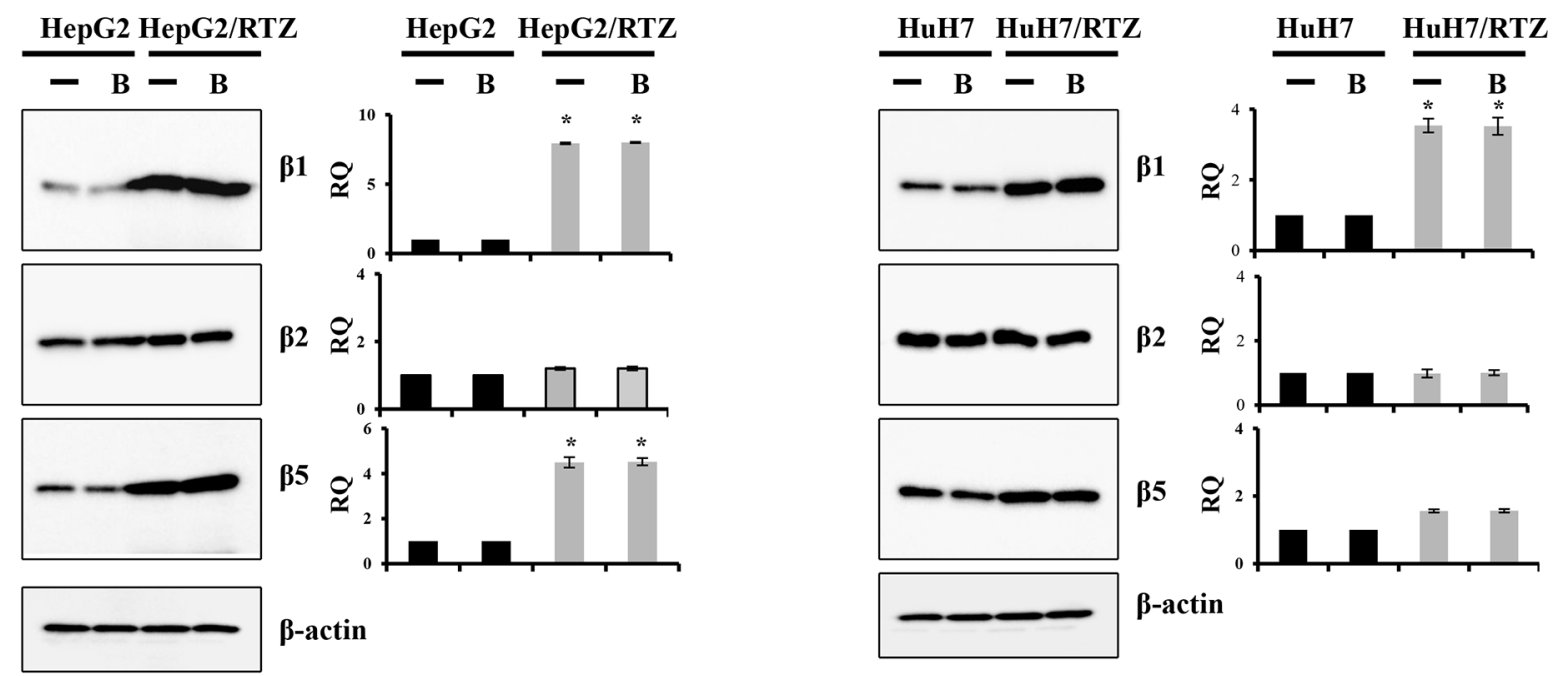

Figure 3: Bortezomib-resistant HCC cells show higher expression of constitutive proteasome subunits. A. The three individual basal activities (CT-L, T-L and PGPH) of proteasomes in wild-type HCC cells were compared with those in bortezomib-resistant HCC cells. Proteasome extracts were prepared from HCC cells. The basal activities of CT-L, T-L, and PGPH were measured using specific fluorogenic peptide substrates for each activity. All results represent the mean \pm SD of three independent experiments. *: $\mathrm{P}<0.01$ as compared with the respective control. B. Western blot of proteasome subunits $(\beta 1, \beta 2$ and $\beta 5)$ and $\beta$-actin in wild-type HepG2, HepG2/ BTZ, wild-type $\mathrm{HuH7}$ and $\mathrm{HuH7/BTZ}$ cells treated with or without $30 \mathrm{nM}$ bortezomib (B) for $24 \mathrm{~h}$. RQ, relative quantity. 
A
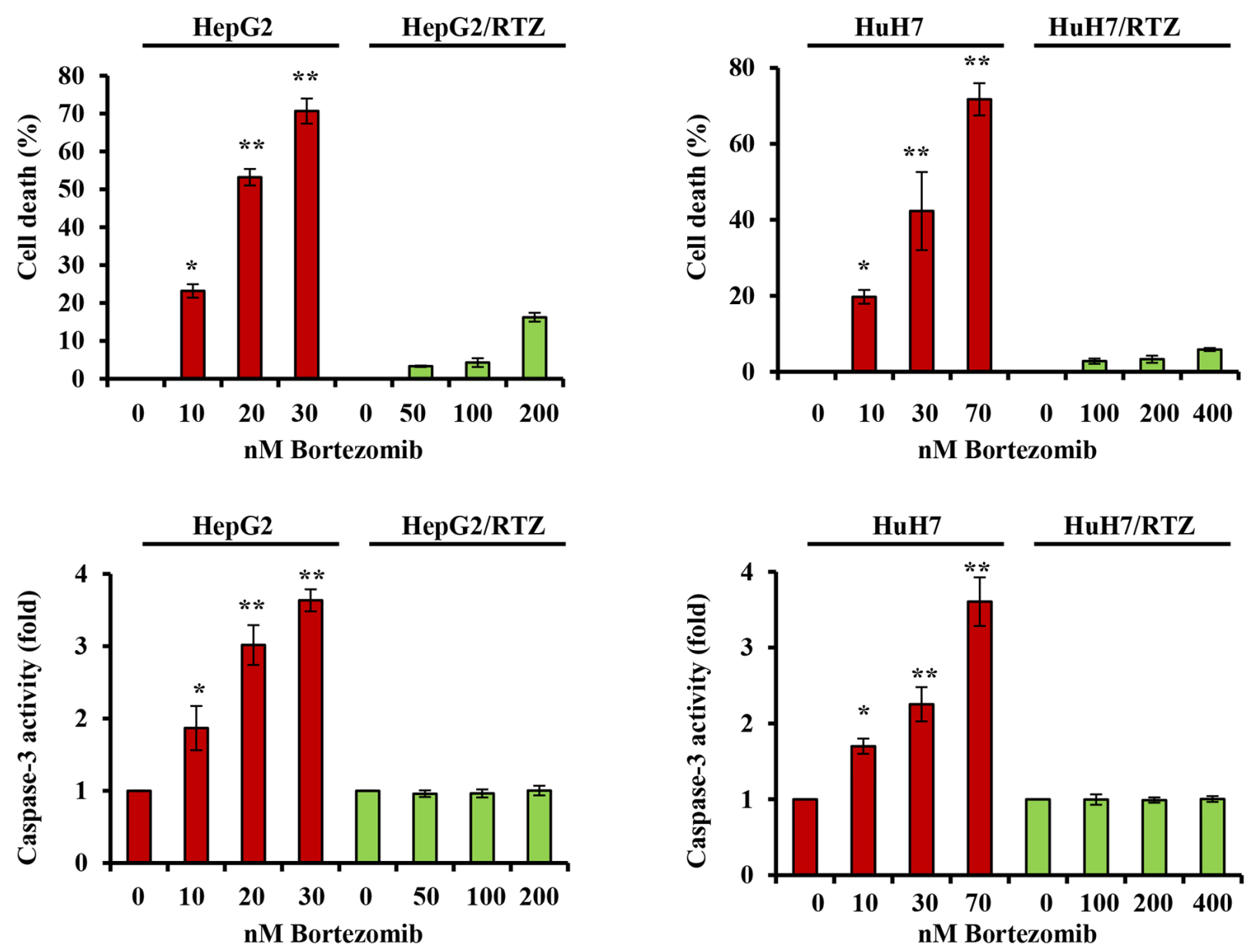

B
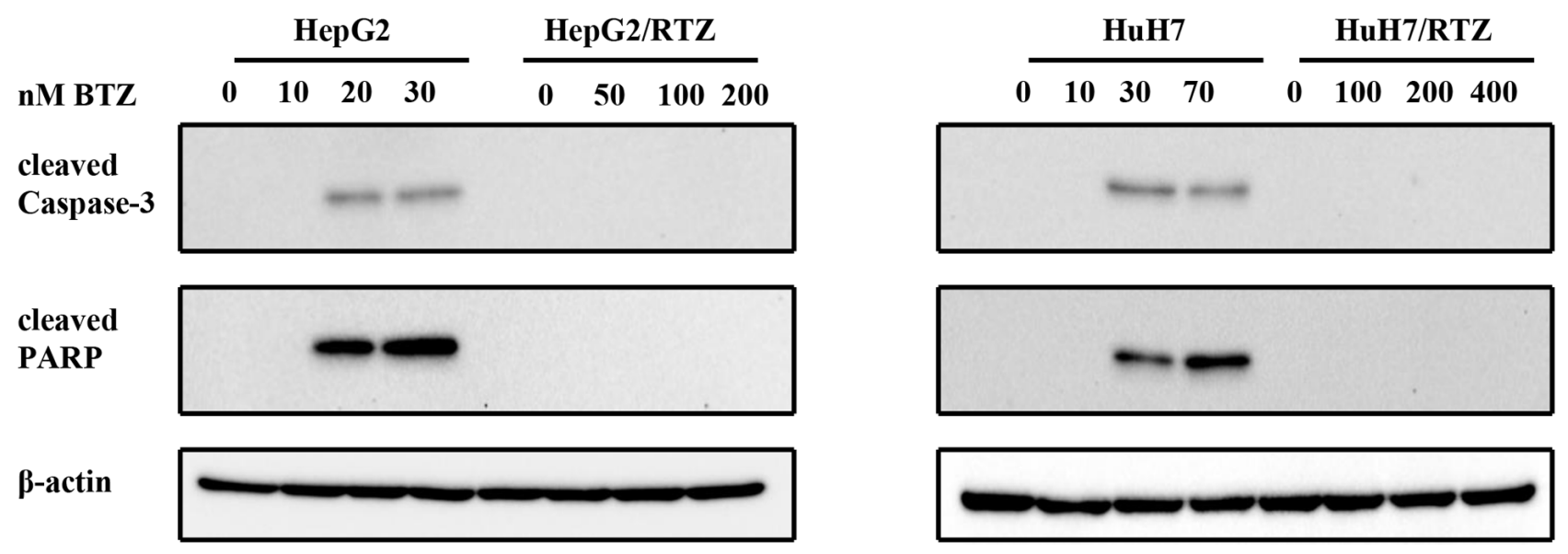

Figure 4: The dose-dependent analysis of caspase-3 activity and the expression of apoptosis-associated proteins in bortezomib-resistant HCC cells and their parental cells. A. Wild-type HepG2, HepG2/BTZ, wild-type HuH7, and HuH7/BTZ cells were treated with various concentrations of bortezomib for $48 \mathrm{~h}$. Apoptosis was then measured by cell viability and caspase-3 activity. **: $P<0.01 ; *: P<0.05$ as compared with the respective control. Data are the mean $\pm \mathrm{SD}$ of three independent experiments. B. Wild-type HepG2, HepG2/BTZ, wild-type $\mathrm{HuH}$ 7, and $\mathrm{HuH} 7 / \mathrm{BTZ}$ cells were treated with various concentrations of bortezomib for $48 \mathrm{~h}$. Expression levels of cleaved PARP, cleaved caspase-3, and $\beta$-actin (loading control) were evaluated by western blot analyses. BTZ, bortezomib. 
of these proteins in bortezomib-resistant $\mathrm{HCC}$ cells and wild-type cells. We investigated alterations in the expression of apoptosis-associated proteins in bortezomibresistant $\mathrm{HCC}$ cells and wild-type cells in the presence of various bortezomib concentrations for $48 \mathrm{~h}$. Data illustrated in Figure 6 indicate that bortezomib caused accumulation of Bax and Noxa in all wild-type cells in a dose-dependent manner, starting at a concentration of 10 to $70 \mathrm{nM}$. Compared with wild-type cells, Bax and Noxa proteins failed to accumulate in response to bortezomib. Additionally, we performed a time-dependent analysis of the expression of apoptosis-associated proteins in bortezomib-resistant HCC cells and wild-type cells. Figure 7 reveals that bortezomib induced a time-dependent increase in the levels of Bax and Noxa in all wild-type cell lines. The maximum effect was observed at $48 \mathrm{~h}$ of treatment. However, compared with wild-type cells, Bax and Noxa proteins failed to accumulate in response to bortezomib in bortezomib-resistant HCC cells. These findings suggested that bortezomib up-regulated proapoptotic proteins Bax and Noxa in dose- and timedependent manners in HCC cells. However, the loss of the ability to stabilize and accumulate pro-apoptotic proteins in bortezomib-resistant HCC cells suggested that it caused the acquired resistance to apoptosis.

\section{DISCUSSION}

Most of the information on bortezomib resistance has been obtained from studies that analyzed individual bortezomib resistances in leukemia and lymphoma cell lines. However, there are no reports of bortezomib resistant in liver cancer. This study is the first to establish and characterize bortezomib-resistant HCC cells. We found that (i) resistance to bortezomib can be achieved in a HCC cell line, (ii) the high basal levels of proteasome activities in bortezomib-resistant HCC cells are due to increased expression of proteasome subunits, and (iii) bortezomib-resistant HCC cells acquire resistance to apoptosis by losing the ability to stabilize and accumulate pro-apoptotic proteins.

The ubiquitin-proteasome pathway system regulates many basic cellular processes including cell cycle, division and apoptosis $[27,28]$. The proteasome complex is made by a 20 s core particle and two $19 \mathrm{~S}$ regulatory particles. The 20s proteasome is cylindrical and consists of two outer rings called $\alpha$-subunits and two inner rings called $\beta$-subunits. There are three major catalytic activities of proteasomes in the 20 s proteasome. They are chymotrypsin-like activity, PGPH activity and trypsin-like activity, corresponding subunits are $\beta 5, \beta 1$ and $\beta 2$ [29]. Bortezomib selectively inhibited chymotrypsin-like and PGPH catalytic activities and appeared to affect the $\beta 1$ and $\beta 5$ subunits [30]. The direct mechanism of bortezomib resistance has been identified at the proteasome level. Recently studies showed that the direct mechanisms of bortezomib resistance in lymphoma, leukemia and lung cancer cell lines are due to $\beta 5$ proteasome subunit overexpression and mutations in the $\beta 5$-subunit. In this study, we found no mutation in the bortezomib-binding pocket of the $\beta$ 5-subunit in HepG2/BTZ and HuH7/BTZ cells. Compared with wild-type cells, chymotrypsin-like
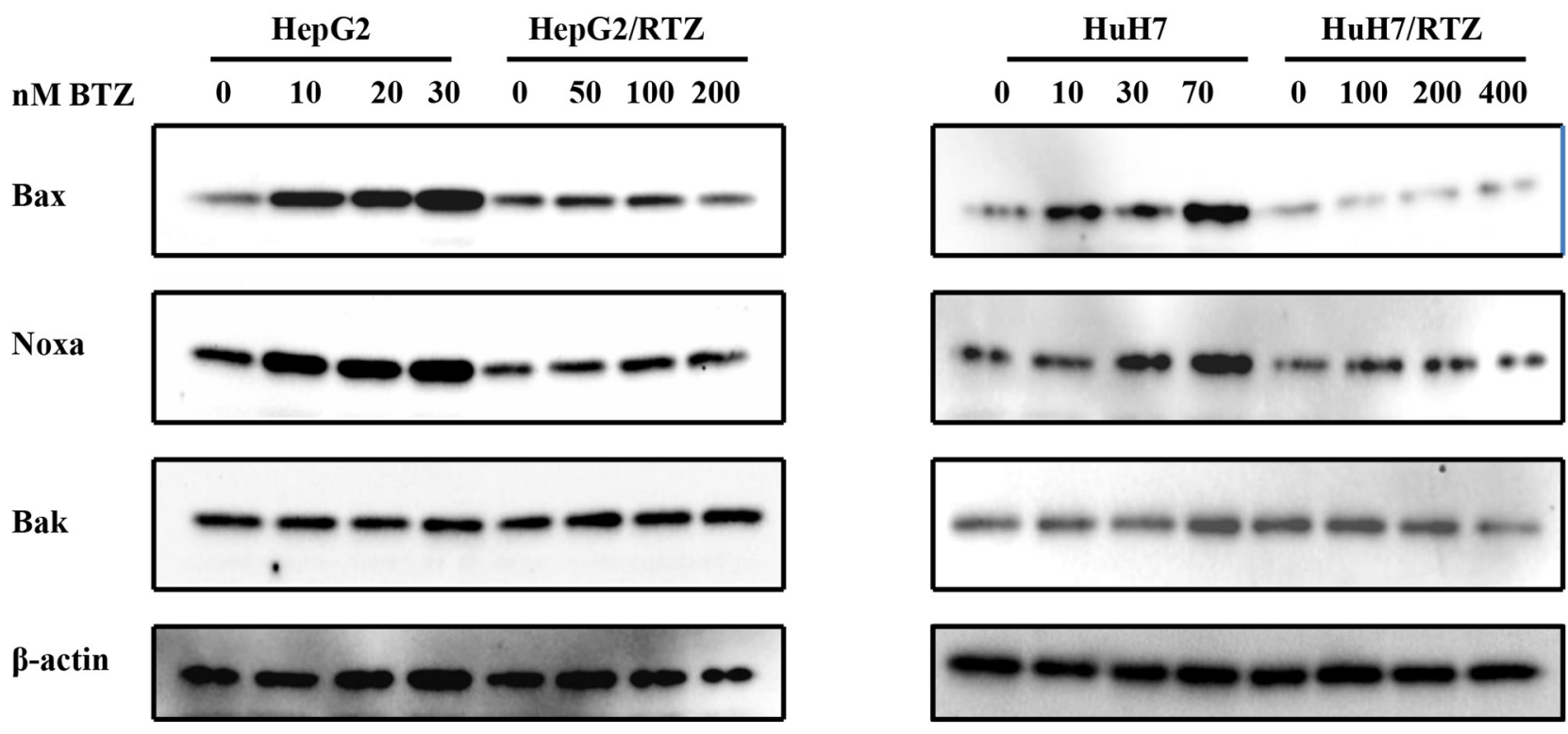

Figure 5: The dose-dependent analysis of Bcl-2 family proteins in bortezomib-resistant $\mathrm{HCC}$ cells and their parental cells. Wild-type HepG2, HepG2/BTZ, wild-type $\mathrm{HuH7}$, and $\mathrm{HuH7/BTZ}$ cells were treated with bortezomib at various concentrations for $48 \mathrm{~h}$. Expression levels of Bax, Noxa, Bak, and $\beta$-actin (loading control) were evaluated by western blot analyses. BTZ, bortezomib. 
A
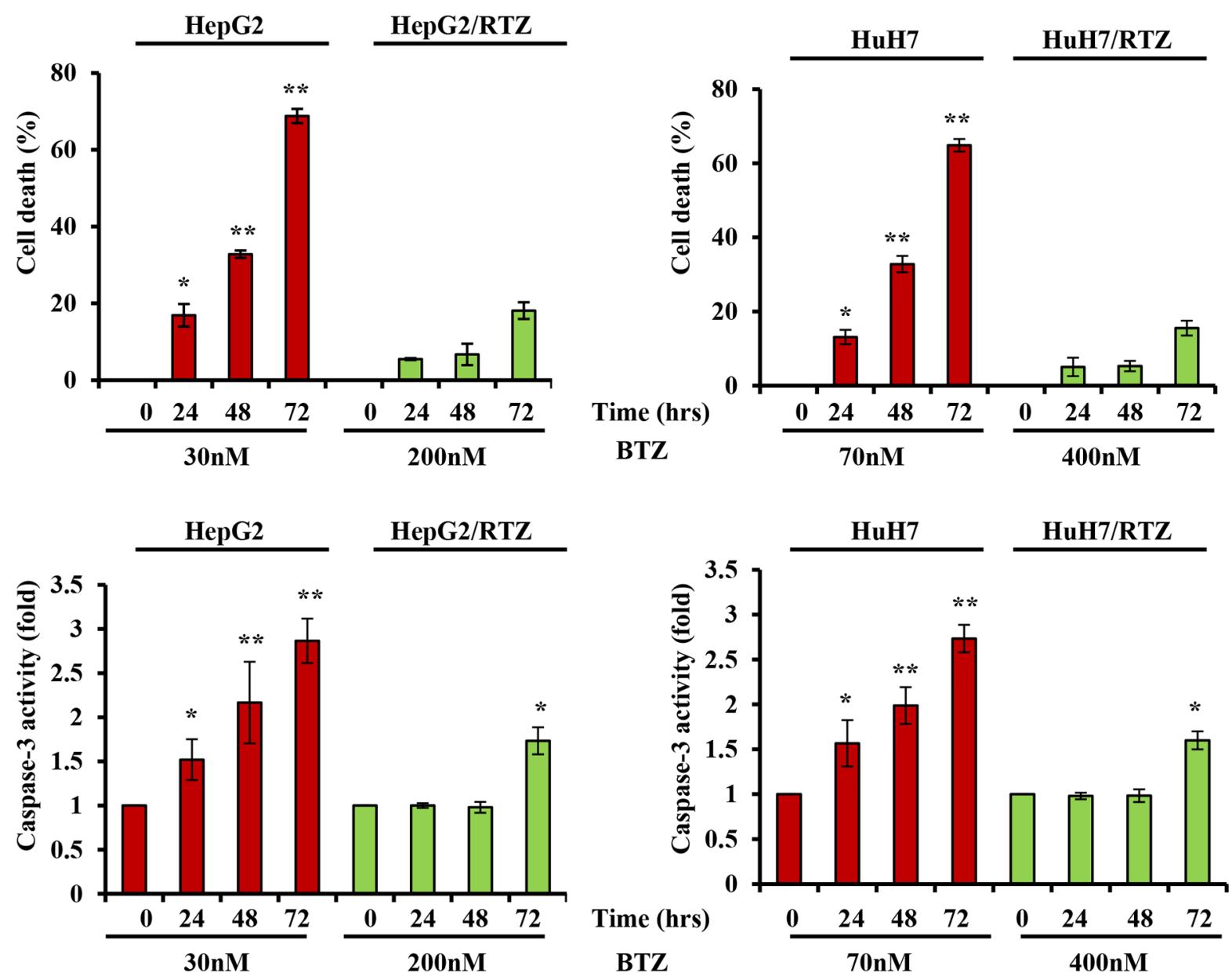

B
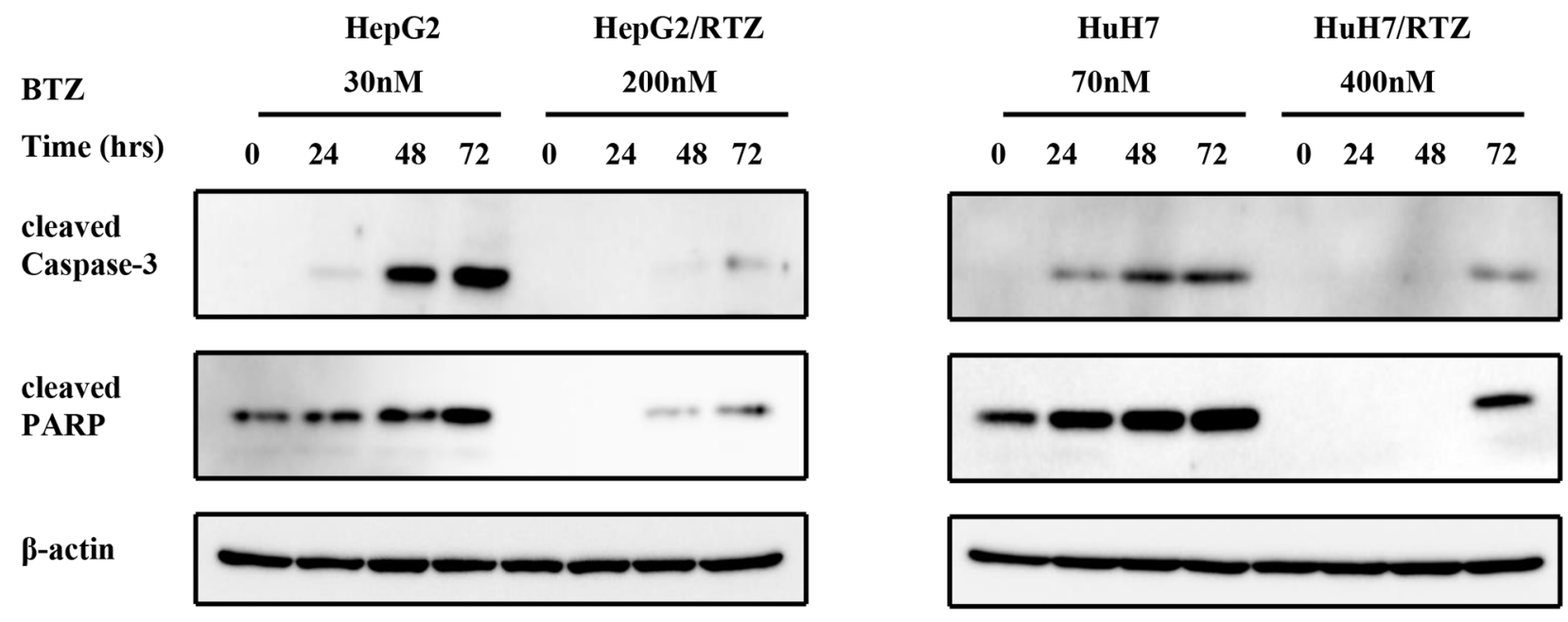

Figure 6: The time-dependent analysis of caspase-3 activity and the expression of apoptosis-associated proteins in bortezomib-resistant HCC cells and their parental cells. A. Wild-type HepG2, HepG2/BTZ, wild-type HuH7, and HuH7/BTZ cells were treated with bortezomib for various times and then apoptosis was measured by cell viability and caspase- 3 activity. **: $P<0.01$; *: $P<0.05$ as compared with the respective control. Data are the mean $\pm \mathrm{SD}$ of three independent experiments. B. Wild-type HepG2, HepG2/ BTZ, wild-type $\mathrm{HuH7}$, and $\mathrm{HuH7/BTZ}$ cells were exposed to bortezomib for the indicated times. Expression levels of cleaved PARP, cleaved caspase-3, and $\beta$-actin (loading control) were evaluated by western blot analyses. BTZ, bortezomib. 
and PGPH activities were 3- and 6 -fold higher in HepG2/ BTZ cells and PGPH activity was 1.9-fold higher in $\mathrm{HuH7/BTZ}$ cells. We also analyzed the expression of the corresponding proteasome subunit. A similar change has been seen in expression level of proteasome. Particularly, expression of the $\beta 1$ and $\beta 5$ subunits was increased in the bortezomib-resistant HepG2 cells, whereas an increase in $\beta 1$ expression was only observed in resistant $\mathrm{HuH7}$ cells. Therefore in bortezomib-resistant HCC cells, the dominant mechanism of resistance at the proteasome level is proteasome subunit over expression. Similar results have been reported recently [31-34]. Kraus et al. reported that bortezomib-adapted HL60 myeloid leukemia cells show increased activity and expression level both of $\beta 1$ and $\beta 5$ proteasome subunits [31]. Rückrich et al. indicated that bortezomib-adapted AMO-1, ARH-77, and HL-60 cell lines (myeloma, plasmacytoid lymphoma, and myeloid leukemia, respectively) show increased activity and expression level of the $\beta$ types of proteasome polypeptides [32]. These increases might partly result from the increased transcription rates of proteasome genes and expression of the respective polypeptides [32]. This notion suggests that the bortezomib resistance is characterized by a reaction pattern including of the upregulation of proteasome gene transcription, expression and activity. Walerych et al. indicated that in cancer cells, p53 missense mutants cooperate with NRF2 to activate proteasome gene transcription, resulting in resistance to the proteasome inhibitor carfilzomib [35]. We did not undertake sequence analysis of TP53 in bortezomib-resistant HCC cells in this study. Whether the same situation is also present in bortezomib-resistant HCC cells should be confirmed in future experiments.

Several mechanisms of proteasome involvement have been deduced in apoptosis. High expression levels of proteasome have been shown to correlate with apoptosis resistance [36-38]. The key role of the proteasome in the regulation of apoptosis is because of its ability to degrade the regulatory molecules involved in apoptosis. A number of proteasome substrates, including Bax, Noxa, and p53, are critically involved in apoptosis [5, 6, 39-41]. Inhibition of proteasome activity results in the accumulation of these target proteins and induction of apoptosis in many types of tumor cells. In this study, bortezomib-resistant HCC cells acquired resistance to apoptosis as shown by caspase- 3 activity as well as caspase- 3 and PARP cleavage (Figure 4 and 6). To confirm the cause of resistance to apoptosis in resistant HCC cells, we examined proteasome-targeting proteins in the regulation of apoptosis. We found that the acquired apoptosis resistance in bortezomib-resistant HCC cells was accompanied by loss of the ability to accumulate and stabilize pro-apoptotic proteins such as Bax and Noxa (Figure 5 and Figure 7).

Several Bcl-2 family proteins control the release of some caspase-activating proteins, such as cytochrome $c$, Smac/DIABLO, and HrtA2/Omi into the cytosol. Release of these caspase-activating proteins can be induced by pro-apoptotic members of the Bcl-2 family, such as Bak, Bax, and Bad, but inhibited by antiapoptotic Bcl-2 family members, such as Bcl-2 and BclXL [42]. Once of the activation of apoptotic signaling, Bax is translocation from cytosol to the organelle

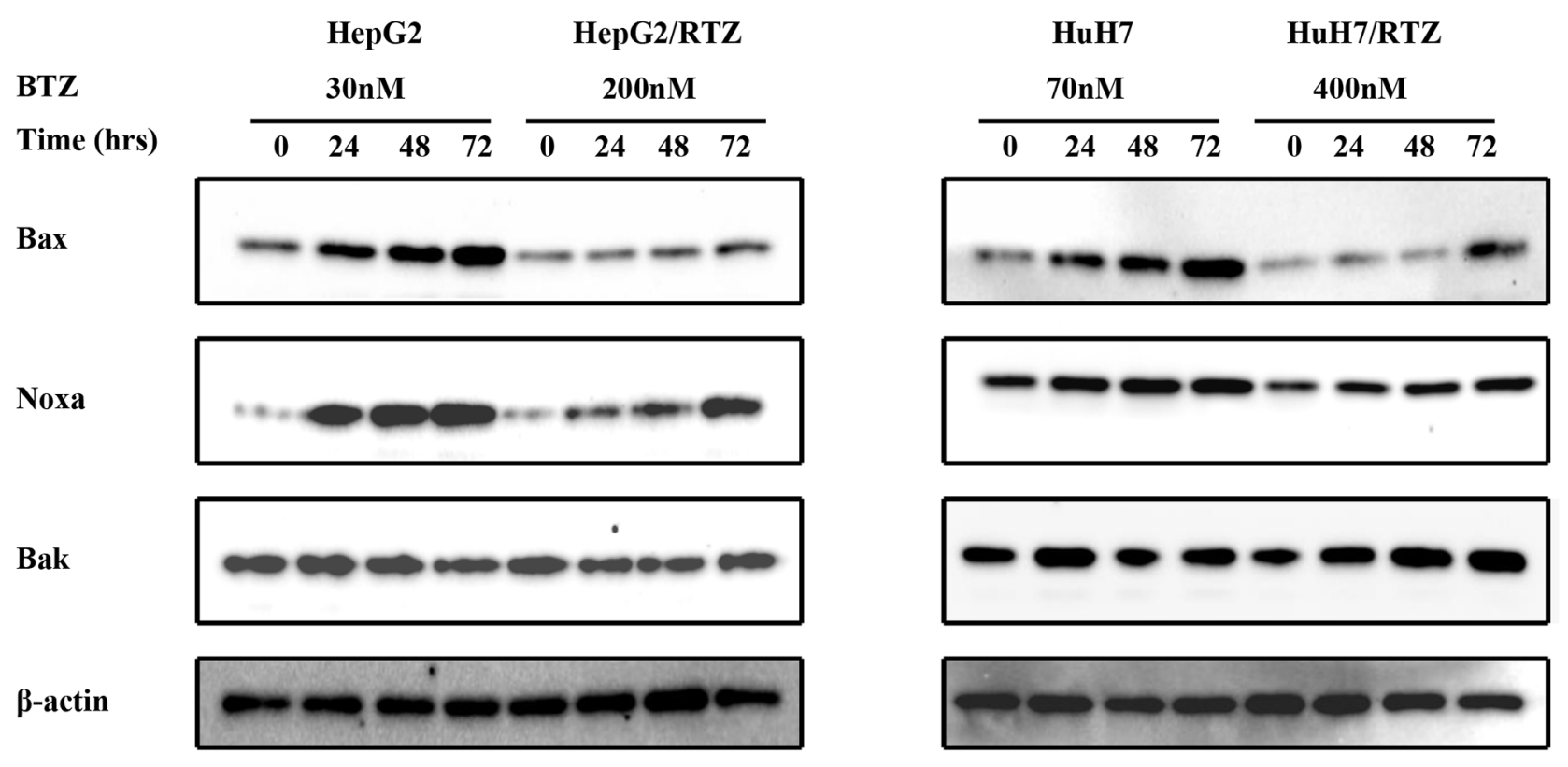

Figure 7: The time-dependent analysis of Bcl-2 family proteins in bortezomib-resistant $\mathrm{HCC}$ cells and their parental cells. Wild-type HepG2, HepG2/BTZ, wild-type HuH7, and HuH7/BTZ cells were exposed to bortezomib for the indicated times. Expression levels of Bax, Noxa, Bak, and $\beta$-actin (loading control) were evaluated by western blot analyses. BTZ, bortezomib. 
membrane, especially the mitochondrial membrane and then permeabilize the mitochondrial outer membrane. As a result, the release of pro-apoptotic factors from mitochondria leads to the activation of caspases. This process defines a direct role of Bax in mediation of apoptotic signaling [43].

Noxa is another pro-apoptotic member of the $\mathrm{Bcl}-2$ protein family [44]. Bax and Bak contain conserved Bcl2 homology $(\mathrm{BH})$ regions $\mathrm{BH} 1, \mathrm{BH} 2$, and $\mathrm{BH} 3$. Noxa is a "BH3-only" type and the most apical regulator of apoptosis. It is activated in response to apoptotic signal and then induces apoptosis [45]. Bax and Noxa are both degraded by ubiquitin-proteasome systems. Treatment with a proteasome inhibitor induces accumulation of Bax and Noxa proteins. In this study, bortezomib caused accumulation of Bax and Noxa in all wild-type HCC cell lines in dose- and time-dependent manners. However, compared with wild-type cells, Bax and Noxa proteins failed to accumulate in response to bortezomib in the bortezomib-resistant HCC cells. Therefore, increased expression of $\beta 1$ and $\beta 5$ proteasome subunits caused the failure of Bax and Noxa accumulation in bortezomibresistant HCC cells and allowed to survive during exposure to bortezomib.

Alterations in the expression of other Bcl-2 family proteins in bortezomib-resistant HCC cells and wild-type cells in the presence of various bortezomib concentrations were not found in this study. The reason may be that these proteins are not correlated by bortezomib in these cells. In addition, several determinants of resistance to bortezomib, such as increased expression level of antiapoptotic Hsp27 protein [26]. The acquired apoptosis is caused by loss of the ability to stabilize and accumulate p53 protein in bortezomib-resistant Burkitt's lymphoma cells [26]. In this study, we did not find differential expression of Hsp27 and p53 proteins between wildtype and bortezomib-resistant $\mathrm{HCC}$ cells. No changing in the expression in all of the BCL-2 family proteins or p53. This means that the function of the mitochondrial pathway - mitochondrial control of apoptosis-is not completely lost in HepG2/RTZ and HuH7/RTZ cells. The DNA damage-p53-mitochondrial pathway-apoptosis cascade was still functional, explaining why HepG2/ RTZ and HuH7/RTZ cells are sensitive to doxorubicin (Table 1).

In this study, we established two stable bortezomibresistant HCC cell lines. There cells display an increase in the expression of proteasome subunits and acquired resistance to apoptosis. After determining the expression of apoptosis related proteins, we found that the ability to accumulate and stabilize Bax and Noxa was lost in these cell lines. Bax and Noxa-induced apoptotic responses were also suppressed. These cell lines will provide useful tools to understand the mechanisms of bortezomib resistance, and to develop of novel therapies for overcome bortezomib resistance.

\section{MATERIALS AND METHODS}

\section{Chemicals and reagents}

Bortezomib was purchased from Selleckchem.com (Selleck Chemicals, Houston, TX, USA), MG-132, MTT (3-[4,5-dimethylthiazol-2-yl]-2,5-diphenyl tetrazolium bromide, were purchased from Sigma-Aldrich (St Louis, MO, USA). The fluorogenic substrates Succ-LLVYAMC (for proteasome chymotrypsin-like subunit), AcRLR-AMC (for proteasome trypsin-like subunit), and Z-LLE-AMC (for proteasome peptidylglutamyl peptide hydrolyzing subunit) and Ac-DEVD-AMC (for caspase-3) were purchased from Enzo Life Sciences (NY, USA).

\section{Cell culture and development of BTZ-resistant cell lines}

The human hepatocellular carcinoma HepG2 cell line was obtained from Riken Cell Bank (Tsukuba, Japan). The hepatocellular carcinoma $\mathrm{HuH7}$ cell lines were obtained from ATCC (USA). All cell lines were cultured in DMEM supplemented with $10 \%$ fetal bovine serum (FBS) and $10 \mu \mathrm{g} / \mathrm{ml}$. penicillin/streptomycin. Cell cultivation was carried out at $37^{\circ} \mathrm{C}$ in a humidified atmosphere of $5 \%$ carbon dioxide and 95\% air. Bortezomib resistant cells were established through a gradual increase in the concentrations of bortezomib for at least 6 months, from $5 \mathrm{nM}$ bortezomib to $1000 \mathrm{nM}$ for HepG2, 40 to $3000 \mathrm{nM}$ for $\mathrm{HuH} 7$, thereby yielding resistant cells named HepG2/ RTZ and HuH7/RTZ. Bortezomib resistant cells were cultured in bortezomib-free medium for at least $72 \mathrm{~h}$ before initiation of experiments to exclude interference of the selective bortezomib concentrations.

\section{Proteasome activity assay in intact cells}

A total of $1 \times 10^{5}$ cells were cells were seeded in white 96 wells plates. For the investigation of proteasome inhibition, cells were exposed to a range of bortezomib concentrations for $3 \mathrm{~h}$. Wishing twice with cold phosphatebuffered saline containing $5 \mathrm{mM} \mathrm{MgCl}_{2}$ and $0.2 \mathrm{mg} /$ $\mathrm{ml}$ digitonin, which permeabilized the cell membrane without disrupting it. Thereafter, $40 \mu \mathrm{l}$ of fluorogenic substrate, Suc-LLVY-AMC, w Z-ARR-AMC, and Z-LLE$\mathrm{AMC}$ as added to each well. After incubation for $3 \mathrm{~h}$ at $37^{\circ} \mathrm{C}$, fluorescence was measured at $380 \mathrm{~nm}$ excitation wavelength and $460 \mathrm{~nm}$ emission wavelength.

\section{Antibodies, reagents and western blot analysis}

Primary antibodies used for western blot analysis were anti-ubiquitin (P4D1) and anti-cleaved caspase-3 (Biolegend, SanDiego, CA, USA), anti-Bax, anti-Noxa, anti cleaved PARP (Santa Cruz Biotechnology, Inc. Santa Cruz, CA, USA), anti- $\beta 1$ subunit of the $26 \mathrm{~S}$ proteasome 
(1:1000) (Abgent, San Diego, CA, anti- $\beta 2$ subunit and anti- $\beta 5$ subunit of the $26 \mathrm{~S}$ proteasome $(1: 1000)$ (Bethyl Lab, Montgomery, TX, USA), USA), anti-actin (1:5000) (Abcam, Cambridge, MA, USA). Secondary antibodies (1:2000) were obtained from Dako, (Agilent Technologies, Böblingen, Germany). SDS-PAGE was performed according to Laemmli (1970) [46]. Cultured cells were lysed in lysis buffer. An equal amount of protein extract from each sample was then separated by SDS-PAGE. After electrophoresis, the gels were transferred onto a polyvinylidene difluoride membrane (Hybond-P PVDF Membrane, Amersham Biosciences, Piscataway, NJ, USA) for immunoblotting. The membranes were blocked with $5 \%$ dry skim milk in TBST buffer $[20 \mathrm{mM}$ Tris-HCl (pH7.5), $150 \mathrm{mM} \mathrm{NaCl}$, and $0.05 \%$ Tween-20] for one hour. After washing in TBST buffer, the membranes were probed with primary antibodies in $1 \%$ BSA/TBST buffer for one hour at room temperature. The primary antibody reactions were detected with peroxidase-conjugated goat anti-rabbit or anti-mouse $\operatorname{IgG}$ in $1 \% \mathrm{BSA}$ /TBST buffer, and signal was detected with the Immune-Lite Chemiluminescent assay kit (Bio-Rad Laboratories, Hercules, CA, USA) according to the manufactuer's specifications.

\section{Preparation of proteasome and enzyme assay}

Proteasome extraction from cells was carried out as described previously [47-50]. Briefly, cells $\left(1 \times 10^{7}\right)$ were harvested, resuspended in $1 \mathrm{ml}$ ATP/DTT lysis buffer $[10 \mathrm{mM}$ Tris- $\mathrm{HCl}(\mathrm{pH} 8), 5 \mathrm{mM}$ ATP, $0.5 \mathrm{mM}$ DTT, $5 \mathrm{mM}$ $\mathrm{MgCl}_{2}$ ], and incubated on ice for $10 \mathrm{~min}$. This was followed by sonication for $15 \mathrm{~s}$. Lysates were centrifuged at $500 \times$ g for $10 \mathrm{~min}$ at $4^{\circ} \mathrm{C}$. The resulting supernatant containing proteasomes was stable at $-80^{\circ} \mathrm{C}$ for $\geq 1$ month with the addition of $20 \%(\mathrm{v} / \mathrm{v})$ glycerol. Protein concentrations of proteasome extractions from mice and cells were measured using a BCA (bicinchoninic acid) protein assay reagent (Thermo Fisher Scientific Inc. Waltham, MA, USA) with bovine serum albumin as a standard. The fluorogenic substrates Succ-LLVY-AMC, Z-ARR-AMC, and Z-LLE-AMC were used to measure chymotrypsin-like (CT-L), trypsin-like (T-L), and peptidylglutamyl peptide hydrolyzing (PGPH) proteasome activities. Assays were carried out in $50 \mu \mathrm{g}, 50 \mathrm{mM}$ EDTA and $50 \mu \mathrm{M}$ fluorogenic substrates in a total volume of $200 \mu 1$ of ATP/DTT lysis buffer at $37^{\circ} \mathrm{C}^{\circ} \mathrm{C}$. The fluorescent rate was determined using a Synergy HT (Bio-TEK Instruments Inc. Winooski, VT, USA) at an excitation wavelength of $395 \mathrm{~nm}$ and emission wavelength of $460 \mathrm{~nm}$.

\section{Cell viability assays and apoptosis assays}

Drug toxicity in cells was determined using the MTT. Cells were seeded in 96-wells plates (IWAKI, Tokyo, Japan) at 5000 cells/well. After 24 h enabling attachment, cells were exposed to increasing concentrations of the proteasome inhibitors for $72 \mathrm{~h}$. Thereafter, cells were incubated for $1 \mathrm{~h}$ with $100 \mu \mathrm{l}$ of $1 \mathrm{mg} / \mathrm{ml}$ MTT solution, followed by addition of $100 \mu 1$ DMSO. Optical density was measured at $540 \mathrm{~nm}$. $\mathrm{IC}_{50}$ values were defined as the concentrations that correspond to a reduction of cell growth by $50 \%$ when compared to values of untreated control cells and depicted as means's. Cell-free caspase-3 activities were determined by measuring the release of the AMC groups from the caspase- 3 specific substrate AcAsp-Glu-Val-Asp-AMC. Briefly, followed by preparation of whole cell extracts, the cell extract $(30 \mu \mathrm{g})$ was then incubated in $100 \mu \mathrm{l}$ of the assay buffer $(50 \mathrm{mM}$ Tris-HCI, $\mathrm{pH} 7.5$ ) with $40 \mu \mathrm{M}$ of substrate. The reaction mixture was incubated at $37^{\circ} \mathrm{C}$ for $30 \mathrm{~h}$ and the hydrolyzed fluorescent $\mathrm{AMC}$ groups were quantified as described above.

\section{Statistical analysis}

Statistical analyses were done with Microsoft Excel software. The Student's $t$-test was applied for independent analysis to evaluate differences between the treatment group and control group.

\section{CONFLICTS OF INTEREST}

The authors declare no conflict of interest.

\section{REFERENCES}

1. Bosch FX, Ribes J, Diaz M, Cleries R. Primary liver cancer: worldwide incidence and trends. Gastroenterology. 2004; 127:S5-S16.

2. El-Serag HB, Rudolph KL. Hepatocellular carcinoma: epidemiology and molecular carcinogenesis. Gastroenterology. 2007; 132:2557-76.

3. Llovet JM, Di Bisceglie AM, Bruix J, Kramer BS, Lencioni R, Zhu AX, Sherman M, Schwartz M, Lotze M, Talwalkar J, Gores GJ. Design and Endpoints of Clinical Trials in Hepatocellular Carcinoma. Journal National Cancer Institute. 2008; 100:698-711.

4. Llovet JM, Bruix J. Molecular targeted therapies in hepatocellular carcinoma. Hepatology. 2008; 48:1312-27.

5. Li B, Dou QP. Bax degradation by the ubiquitiny/ proteasome-dependent pathway: Involvement in tumor survival and progression. Proceedings of the National Academy of Sciences of the United States of America. 2000; 97:3850-55.

6. Naujokat C, Hoffmann S. Role and function of the $26 \mathrm{~S}$ proteasome in proliferation and apoptosis. Laboratory investigation. 2002; 82:965-80.

7. Kane RC, Bross PF, Farrell AT, Pazdur R. Velcade: U.S. FDA approval for the treatment of multiple myeloma progressing on prior therapy. Oncologist. 2003; 8:508-13. 
8. Richardson PG, Mitsiades C, Hideshima T, Anderson KC. Bortezomib: proteasome inhibition as an effective anticancer therapy. Annual Review of Medicine. 2006; 57:33-47.

9. Papandreou CN, Daliani DD, Nix D, Yang H, Madden T, Wang X, Pien CS, Millikan RE, Tu SM, Pagliaro L, Kim J, Adams J, Elliott P, et al. Phase I trial of the proteasome inhibitor bortezomib in patients with advanced solid tumors with observations in androgen-independent prostate cancer. Journal of Clinical Oncology. 2004; 22:2108-21.

10. Voortman J, Smit EF, Honeywell R, Kuenen BC, Peters GJ, van de Velde H, Giaccone G. A parallel doseescalation study of weekly and twice-weekly bortezomib in combination with gemcitabine and cisplatin in the first-line treatment of patients with advanced solid tumors. Clinical Cancer Research. 2007; 13:3642-51.

11. Shah MH, Young D, Kindler HL, Webb I, Kleiber B, Wright J, Grever M. Phase II study of the proteasome inhibitor bortezomib (PS-341) in patients with metastatic neuroendocrine tumors. Clinical Cancer Research. 2004; 10:6111-8.

12. Davis NB, Taber DA, Ansari RH, Ryan CW, George C, Vokes EE, Vogelzang NJ, Stadler WM. Phase II trial of PS-341 in patients with renal cell cancer: a University of Chicago phase II consortium study. Journal of Clinical Oncology. 2004; 22:115-9.

13. Hegewisch-Becker S, Sterneck M, Schubert U, Rogiers X, Guerciolini R, Pierce JE, Hossfeld DK. Phase I/II trial of botrezomib in patients with unresectable hepatocellular carcinoma. Journal of Clinical Oncology. 2004; 22:4089.

14. Kim GP, Mahoney MR, Szydlo D, Mok TS, Marshke R, Holen K, Picus J, Boyer M, Pitot HC, Rubin J, Philip PA, Nowak A, Wright JJ, Erlichman C. An international, multicenter phase II trial of bortezomib in patients with hepatocellular carcinoma. Investigational New Drugs. 2012; 30:387-94.

15. Oerlemans R, Franke NE, Assaraf YG, Cloos J, van Zantwijk I, Berkers CR, Scheffer GL, Debipersad K, Vojtekova K, Lemos C, van der Heijden JW, Ylstra B, Peters GJ, et al. Molecular basis of bortezomib resistance: proteasome subunit $\beta 5$ (PSMB5) gene mutation and overexpression of PSMB5 protein. Blood. 2008; 112:2489-99.

16. Ri M, Iida S, Nakashima T, Miyazaki H, Mori F, Ito A, Inagaki A, Kusumoto S, Ishida T, Komatsu H, Shiotsu Y, Ueda R. Bortezomib-resistant myeloma cell lines: a role for mutated PSMB5 in preventing the accumulation of unfolded proteins and fatal ER stress. Leukemia. 2010; 24:1506-12.

17. de Wilt LH, Jansen G, Assaraf YG, van Meerloo J, Cloos F, Schimmer AD, Chan ET, Kirk CJ, Peters GJ, Kruyt FA. Proteasome-based mechanisms of intrinsic and acquired bortezomib resistance in non-small cell lung cancer. Biochemical Pharmacology. 2012; 83:207-17.

18. Kim A, Seong KM, Kang HJ, Park S, Lee SS. Inhibition of Lyn is a promising treatment for mantle cell lymphoma with bortezomib resistance. Oncotarget. 2015; 6:38225-38. doi: 10.18632/oncotarget.5425.

19. Raninga PV, Di Trapani G, Vuckovic S, Bhatia M, Tonissen KF. Inhibition of thioredoxin 1 leads to apoptosis in drugresistant multiple myeloma. Oncotarget. 2015; 6:15410-24. doi: 10.18632/oncotarget.3795.

20. Siegel MB, Liu SQ, Davare MA, Spurgeon SE, Loriaux MM, Druker BJ, Scott EC, Tyner JW. Small molecule inhibitor screen identifies synergistic activity of the bromodomain inhibitor CPI203 and bortezomib in drug resistant myeloma. Oncotarget. 2015; 6:18921-32. doi: 10.18632/oncotarget.4214.

21. Fristedt Duvefelt $\mathrm{C}$, Lub $\mathrm{S}$, Agarwal $\mathrm{P}$, Arngården L, Hammarberg A, Maes K, Van Valckenborgh E, Vanderkerken K, Jernberg Wiklund H. Increased resistance to proteasome inhibitors in multiple myeloma mediated by cIAP2--implications for a combinatorial treatment. Oncotarget. 2015; 6:20621-35. doi: 10.18632/ oncotarget.4139.

22. Zhang M, He J, Liu Z, Lu Y, Zheng Y, Li H, Xu J, Liu H, Qian J, Orlowski RZ, Kwak LW, Yi Q, Yang J. Anti$\beta_{2}$-microglobulin monoclonal antibodies overcome bortezomib resistance in multiple myeloma by inhibiting autophagy. Oncotarget. 2015; 6:8567-78. doi: 10.18632/ oncotarget.3251.

23. Jaganathan S, Malek E, Vallabhapurapu S, Vallabhapurapu $\mathrm{S}$, Driscoll JJ. Bortezomib induces AMPK-dependent autophagosome formation uncoupled from apoptosis in drug resistant cells. Oncotarget. 2014; 5:12358-70. doi: 10.18632/oncotarget.2590.

24. Falchook GS, Wheler JJ, Naing A, Jackson EF, Janku F, Hong D, Ng CS, Tannir NM, Lawhorn KN, Huang M, Angelo LS, Vishwamitra D, Hess K, et al. Targeting hypoxia-inducible factor- $1 \alpha$ (HIF-1 $\alpha$ ) in combination with antiangiogenic therapy: a phase I trial of bortezomib plus bevacizumab. Oncotarget. 2014; 5:10280-92. doi: 10.18632/oncotarget.2163.

25. Chauhan D, Li G, Shringarpure R, Podar K, Ohtake Y, Hideshima T, Anderson KC. Blockade of Hsp27 overcomes Bortezomib/proteasome inhibitor PS-341 resistance in lymphoma cells. Cancer Research. 2003; 63:6174-77.

26. Fuchs D, Berges C, Opelz G, Daniel V, Naujokat C. Increased expression and altered subunit composition of proteasomes induced by continuous proteasome inhibition establish apoptosis resistance and hyperproliferation of Burkitt lymphoma cells. Journal of Cellular Biochemistry. 2008; 103:270-8.

27. Ciechanover A. The ubiquitin-proteasome pathway: on protein death and cell life. EMBO J. 1998; 17:7151-60.

28. Hershko A, Ciechanover A. The ubiquitin system. Annual Review of Biochemistry. 1998; 67:425-79.

29. Groll M, Heinemeyer W, Jäger S, Ullrich T, Bochtler M, Wolf DH, Huber R. The catalytic sites of 20S proteasome and their role in subunit maturation: a mutational and crystallographic study. Proceedings of the National 
Academy of Sciences of the United States of America. 1999; 96:10976-83.

30. Adams J. The proteasome: structure, function, and role in the cell. Cancer Treatment Reviews. 2003; 29:Supplement1; 3-9.

31. Kraus M, Rückrich T, Reich M, Gogel J, Beck A, Kammer W, Berkers CR, Burg D, Overkleeft H, Ovaa H, Driessen C. Activity patterns of proteasome subunits reflect bortezomib sensitivity of hematologic malignancies and are variable in primary human leukemia cells. Leukemia. 2007; 21:84-92.

32. Rückrich T, Kraus M, Gogel J, Beck A, Ovaa H, Verdoes M, Overkleeft S, Kalbacher H, Driessen C. Characterization of the ubiquitin-proteasome system in bortezomib-adapted cells. Leukemia. 2009; 23:1098-105.

33. Liu Y, Liu X, Zhang T, Luna C, Liton PB, Gonzalez P. Cytoprotective effects of proteasome $\beta 5$ subunit overexpression in lens epithelial cells. Molecular Vision. 2007; 13:31-8.

34. Busse A, Kraus M, Na IK, Rietz A, Scheibenbogen C, Driessen C, Blau IW, Thiel E, Keilholz U. Sensitivity of tumor cells to proteasome inhibitors is associated with expression levels and composition of proteasome subunits. Cancer. 2008; 112:659-70.

35. Walerych D, Lisek K, Sommaggio R, Piazza S, Ciani Y, Dalla E, Rajkowska K, Gaweda-Walerych K, Ingallina E, Tonelli C, Morelli MJ, Amato A, Eterno V, et al. Proteasome machinery is instrumental in a common gain-of-function program of the p53 missense mutants in cancer. Nature Cell Biology. 2016; 18:897-909.

36. Ohkawa K, Asakura T, Aoki K, Shibata S, Minami J, Fujiwara C, Sai T, Marushima H, Kuzuu H. Establishment and some characteristics of epoxomicin (a proteasome inhibitor) resistant variants of the human squamous cell carcinoma cell line, A431. International Journal of Oncology. 2004; 24:425-33.

37. Ci X, Li B, Ma X, Kong F, Zheng C, Björkholm M, Jia J, $\mathrm{Xu}$ D. Bortezomib-mediated down-regulation of telomerase and disruption of telomere homeostasis contributes to apoptosis of malignant cells. Oncotarget. 2015; 6:3807992. doi: 10.18632/oncotarget.5752.

38. Sun X, Ackerstaff E, He F, Xing L, Hsiao HT, Koutcher JA, Ling CC, Li GC. Visualizing the antivascular effect of bortezomib on the hypoxic tumor microenvironment. Oncotarget. 2015; 6:34732-44. doi: 10.18632/oncotarget.5300.

39. An WG, Hwang SG, Trepel JB, Blagosklonny MV. Protease inhibitor-induced apoptosis: accumulation of wt p53, p21WAF1/CIP1, and induction of apoptosis are independent markers of proteasome inhibition. Leukemia. 2000; 14:1276-83.

40. Minderman H, Zhou Y, O'Loughlin KL, Baer MR. Bortezomib activity and in vitro interactions with anthracyclines and cytarabine in acute myeloid leukemia cells are independent of multidrug resistance mechanisms and p53 status. Cancer Chemotherapy and Pharmacology. 2007; 60:245-55.

41. Leshchenko VV, Kuo PY, Jiang Z, Weniger MA, Overbey J, Dunleavy K, Wilson WH, Wiestner A, Parekh S. Harnessing Noxa demethylation to overcome Bortezomib resistance in mantle cell lymphoma. Oncotarget. 2015; 6:27332-42. doi: 10.18632/oncotarget.2903.

42. Cory S, Adams JM. The Bcl2 family: regulators of the cellular life-or-death switch. Nature Reviews Cancer. 2002; 2:647-56.

43. Wei MC, Zong WX, Cheng EH, Lindsten T, Panoutsakopoulou V, Ross AJ, Roth KA, MacGregor GR, Thompson CB, Korsmeyer SJ. Proapoptotic BAX and $\mathrm{BAK}$ : a requisite gateway to mitochondrial dysfunction and death. Science. 2001; 292:727-30.

44. Oda E, Ohki R, Murasawa H, Nemoto J, Shibue T, Yamashita T, Tokino T, Taniguchi T, Tanaka N. Noxa, a BH3-only member of the Bcl-2 family and candidate mediator of p53induced apoptosis. Science. 2000; 288:1053-1058.

45. Labi V, Erlacher M, Kiessling S, Villunger A. BH3-only proteins in cell death initiation, malignant disease and anticancer therapy. Cell Death and Differentiation. 2006; 13:1325-38

46. Laemmli UK. Cleavage of structural proteins during the assembly of the head of bacteriophage T4. Nature. 1970; 227:680-5.

47. Wu XY, Sato E, Kimura W, Miura N. Baicalin and scutellarin are proteasome inhibitors that specifically target chymotrypsin-like catalytic activity. Phytotherapy Research. 2013; 27:1362-7.

48. Crawford LJ, Walker B, Ovaa H, Chauhan D, Anderson KC, Morris TC, Irvine AE. Comparative selectivity and specificity of the proteasome inhibitors Bzlllcocho, PS-341, and Mg-132. Cancer Research. 2006; 66:6379-86.

49. Wu XY, Fang X. Apigenin, chrysin, and luteolin selectively inhibit the chymotrypsin-like and trypsin-like proteasome catalytic activities in tumor cells. Planta Medica. 2010; 76:128-32.

50. Nakamura K, Yang JH, Sato E, Miura N, Wu YX. Effects of hydroxy groups in the A-ring on the anti-proteasome activity of flavone. Biological and Pharmaceutical Bulletin. 2015; 38:935-40. 